\title{
Turn the tide on losing members to cults: The challenge of the churches in the Congo
}

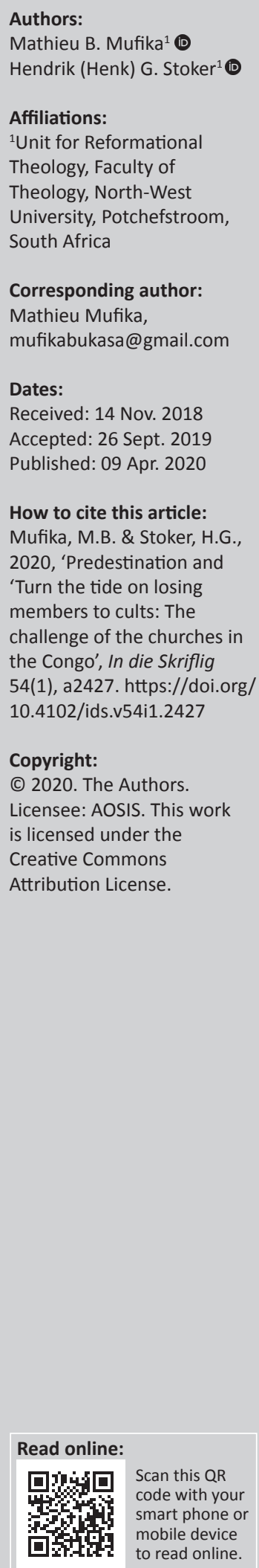

\begin{abstract}
Especially since the late 20th century, former 'Western' cults such as the Jehovah Witnesses, Mormons and Branhamites, became a real threat to churches in the greater Kolwezi, the rest of the Democratic Republic of Congo (DRC) and several other places in Africa. Because these cultic groups question some of the most basic teachings of Christianity, including who God is and whether salvation occurs through Jesus Christ alone, it is crucial for Christian churches confronted with them, to respond apologetically in an effective way. To be able to do it, it is important to understand why these groups made such inroads and proselytes from Christian churches. In the article such background is given and a way forward through Christian apologetics and a missionary strategy is discussed.
\end{abstract}

Keywords: Cults; Apologetics; DRC; Jehovah Witnesses; Branhamites.

\section{Introduction}

A religious cult can be described as a religious group that pursuits to control both the earthly life and the eternal destiny of its members. This usually entails control over thinking, conduct and emotions, as well as control over information and environment, language, norms, God, salvation, the Bible (or their book of authority), doctrines, history and membership.

To gain converts and strengthen their position, cults are known for delivering of widespread criticism of the Christian doctrines through literature and media (Baker 2006:5). Where Christians are not well grounded in the reasons for their beliefs (Gruss 1970:4), cults find fertile ground - such is the case in Kolwezi and other parts of the Democratic Republic of Congo (DRC). A study of the situation in Kolwezi (Mufika 2017) showed most Christians (and also their pastors) are uninformed of the history, doctrines and methods of the cults active in their region such as the Jehovah's Witnesses, Mormons and Branhamites, as well as how these groups deviate from Christianity and how to respond to them. It became clear that Christians in Kolwezi urgently need to understand their own doctrine of God as Trinity, as well as what salvation in Jesus Christ entails. The same is true of Christians in many other cities and places in Africa. Gruss (1979:91) himself a former Jehovah's Witness, argues that Christians' failure to understand and witness their belief, is an important factor for the emergence of the cults. This happens according to Dencher (1961:52-53), even while cults are unable to offer the experience of true salvation, peace and happiness, all which is part of true Christianity.

Christian leaders should be able to read, explore and analyse the critical challenge from the cults and compare these teachings to that of the biblical testimony. This article aims not only to give insight in what is happening in this regard, but also to support these Christian churches and their leaders by responding apologetically to certain major teachings of the Jehovah's Witnesses, Mormons and Branhamites. If Christian apologists could be identified and trained to approach members of the Jehovah's Witnesses, Mormons and Branhamites with love, friendliness and the true biblical doctrine, it may not only strengthen the Christian churches in Kolwezi, but also influence the current development of the situation in other parts of the DRC and its next door neighbours. If the members from the cults can be confronted with the truth of the Scripture message, such truth can set them free (Jn 8:36-38).

\section{Cultic doctrines}

As early as 1941, the Watch Tower Bible and Tract Society (better known as Jehovah's Witnesses) published material that opposes the core Christian belief of a triune God in their booklet Let God to be true (Watchtower Bible and Tract Society [WTBTS] 1941:100-111). In this book, the Christian doctrine of the divinity of Christ is strongly denied. This criticism was presented by the spreading 
of thousands of copies of this book in the major languages used in Kolwezi such as Kiswahili, Kisanga, Kiluba, Kikaonde, Ndembu and French.

The Branhamites are also in fierce opposition to the Christian doctrine of the Trinity - but for reasons other than those held by the Jehovah's Witnesses. Their founder, William M. Branham, emphasised as early as 1953 that only Christ is God, manifesting himself simultaneously in three offices or roles, namely as the Father, as the Son and as the Holy Spirit.

Although Branham called it a new revelation, he in effect adopted the modalistic view of Sabellianism (Wilson 1988:95-97). The influence of this teaching is so significant, that in several Pentecostal and Independent Churches in Kolwezi, the Apostles' Creed is no longer confessed. People pray in these churches by repeatedly using the expression, 'Father God Jesus'. Under the influence of Branhamism, numerous believers in Kolwezi understand God the Father simply as Jesus of Nazareth (Mufika 2017). It is being done even if this doctrine is clearly in contrast with several parts of the Bible, such as can be seen in what Jesus told his disciples in John 14, as well as his prayer to God the Father in John 17.

While the Jehovah's Witnesses retort that Jesus is not God Almighty, but the first creature created by God (WTBTS 1941), the Branhamites on the other hand, contend that only Jesus is the true God of the Bible (Branham 1963:9-20). Ironically, both the Jehovah's Witnesses and Branhamites use similar methods and believe similar major doctrines in opposition to Christianity. Both groups believe more in the teachings and calling of the respective founders of the organisation than in what Christ reveals about himself and his Father; they trust more in the organisation's literature than in Scripture itself (Bowman 1995:20; Dencher 1961:19); they deny the Trinity, the bodily resurrection of Christ, biblical salvation only through faith in Jesus and not by works; they both reject other churches and parts of the Apostles' Creed, because they claim that only their organisation is the true church and God's sole organisation on earth; they both prophesied the end of the world at certain dates, which did not happen.

\section{Historical development in the Democratic Republic of Congo favouring the cults}

After the independence of the Congo in the 1960s, the recruitment of pastors for Christian churches in the DRC was not based on training as is normally the case. The focus changed to testimonies, gifts and amicable relationships with the church. Western missionaries have been forced to leave the country and left a gap with only uneducated laymen to fill it (Burton 1961:174-180; Garrard 2008:20-30). The Jehovah's Witnesses and Branhamites seized the opportunity of civil war, violence, suffering, poverty, tribal conflict and ignorance by proclaiming their end-time prophecies and criticising Christianity and basic Christian doctrines.
Through these influences, the doctrine of the Trinity has even become a taboo in several Christian churches in Kolwezi.

There is indeed a dire need for Christians in Kolwezi and the DRC to understand their own beliefs and the reason for it.

For centuries Arianism challenged fundamental Christian beliefs such as the deity of Christ. However, this heresy could not succeed in eradicating or replacing Christianity in the West. By claiming to be Christian and truly biblical, the Jehovah's Witnesses and Branhamites, however, have been spreading this age-old heresy to a Christian community with immature Christians and uneducated pastors. As a result, numerous of these gullible believers have accepted these teachings and joined the ranks of the mentioned cults.

It is difficult to overestimate the impact of the Catholic Church in the DRC and some called it the country's 'only truly national institution apart from the state'. Besides involving over $40 \%$ of the population of the Congo in its religious service, its schools have educated over $60 \%$ of the nation's primary school students and more than $40 \%$ of its secondary school students. The church owns and manages an extensive network of hospitals, schools and clinics, as well as many diocesan economic enterprises, including farms, ranches, stores and artisan shops. This was possible due to the complete support of the Belgian administration of King Leopold II, especially through his Bishop, Jean Felix de Hemptinne. The church was so involved with colonialism that it could be counted a second force in the Congo.

The first local cardinal, Joseph Albert Malula (Archdiocese of Kinshasa) said: 'For our people, the church was the state, and the state was the church' (Malula 1970:40, 60).

In 1965, Colonel Mobutu took the presidency of the DRC after a coup to lead the country between 1965 and 1997. His regime was very authoritative, dictatorial and corrupt. As he lacked governing skills, he led the country unto extreme poverty and need for change (Kisangani \& Bobb 2010). As a result, the Catholic Church distanced itself from the state and the state became most critical of the Roman Catholic Church. Conflict erupted in 1971 when the state centralised and extended its authority, nationalised the country's universities, including the Catholic Church's Lovanium outside of Kinshasa (Kisangani \& Bobb 2010). The state attempted to implant the official party's youth movement, the Youth of the Popular Revolutionary Movement (in French: Jeunesse du Mouvement Populaire de la Revolution) in Catholic seminaries, and this was strongly resisted.

In 1972 the conflict intensified when all Zairians were ordered to drop their Christian baptismal names and to adopt African ones as part of the 'Authenticity campaign'. The president took the lead. His Christian name was Joseph Desiré Mobutu, but now it became Mobutu Sese Seko Kuku Ngbendu Wa ZaBanga (Mobutu Sese Seko for short), which means 'Mobutu the eternal' (Kisangani \& Bobb 2010). Cardinal Malula objected against the decision and told his bishops to ignore it. 
The regime retaliated by forcing the cardinal into exile for three months and by seizing his residence and converted it into a Jeunesse Mouvement Populaire de la Revolution (JMPR) headquarter. In addition, the state banned all religious publications and youth groups (Kisangani \& Bobb 2010).

Since 1997, with the presidency of Laurent Kabila, cults such as Jehovah's Witnesses and Branhamites enjoyed significant growth in Kolwezi. Kabila's regime allowed these groups to work freely but they were 'forced' to criticise the Christian church (and not his regime).

\section{The rise of the cults in Kolwezi The Jehovah's Witnesses organised mission field in the Democratic Republic of Congo (1960-2014)}

During the colonial period (1905-1960) the Belgians did not allow other religious groups to teach and preach, only Christian churches. The Belgians banned the Society of Jehovah's Witnesses for decades. After the independence of the DRC (1960), the new government led by President Joseph Kasa-Vubu, provided an opportunity for the Jehovah's Witnesses mission. The latter seized the opportunity by sending many missionaries to the Congo. The presence of Jehovah's Witnesses missionaries in Kinshasa helped to increase the number of publishers (propagators or distributors of their literatures) to approximately 2000 in 1962, and the attendants to about 6000 members. In March 1964, several more Jehovah's Witnesses missionaries arrived in the Congo. They were sent to the different regions in the DRC.

\section{Circuits and missionary homes opened}

In 1966, the first Jehovah's Witnesses missionary home outside Kinshasa was opened in Lubumbashi, in the southeast of the country. The yearbook of 2004 reports on the work in the DRC. From 1968 to 1986, over 60 missionaries served in different parts of the country (WTBTS 2004:165-215). In 1967 and 1968, a missionary home was opened in Kolwezi, northwest of Lubumbashi, and in Kananga in the Kasai province.

Circuits were opened locally after the Jehovah's Witnesses trained several distributors (also called 'publishers'), and pioneer teams were sent into remote areas of large cities such as Lubumbashi, Likasi, Kolwezi, Kamina and Kalemie. The presence of these missionaries had a strong stabilising influence on the adherents that helped the witnesses live out the strict doctrine of the organisation in the Congo.

\section{Annual conventions increase the numbers}

A Jehovah's Witnesses convention consisted of the organisation of circuit assemblies (i.e. 10-15 circuits meeting in a large hall, stadium, or in open air). Jehovah's Witnesses had the authorisation to hold such large conventions, but intensive preparation was necessary beforehand. They had to organise Bible dramas, which required costumes. They also needed a sound system to attract more people. The attendance varied from 11214 to 30400 individuals, and at one such event, 465 were baptised in Kinshasa (WTBTS 1971; 2004).
In the 1970s, the focus fell on market traders. The Jehovah's Witnesses sent pioneers to work in the market for two months at a time, preaching individually according to their method. In the 1980s, new home missionaries were added to Kolwezi to handle the increase in followers (WTBTS 2004). A second group focused their ministry on the rural areas around Kolwezi. In 1985, the publishers increased to approximately 500. Compared to mainstream churches, this number was still insignificant. The sects' strategy of training publishers and Bible teachers was qualitative and highly productive.

Teachers in schools were targeted to become key role-players in leading the masses. It stands to reason: if a teacher is turned into an effective witness, the whole class can be reached to underwrite their vision of Jehovah's kingdom. It is staggering to consider how many learners 100 teachers can reach in a year or five years' time in the Congo if a class contains approximately 50-65 learners.

The national office submitted a draft for a project to extend the kingdom halls throughout the country. As many as 10000 new kingdom halls were erected from 2005 to 2015.

\section{Influence of Branhamism in Kolwezi}

The Movement of William Marrion Branham's followers (Branhamism) was introduced in the DRC around 1984 throughout the capital city of Kinshasa. Presently, adherents are found in every province of the country. The statistics of the Branhamites show an immense growth in the 30 years since the middle-1980s. In 1985, there were only 300 followers of Branham in the city of Kolwezi, whereas in 1990 they were reaching 3000; in 2010 approximately 9000, and by 2014 there were 12000 members (Palmier TV 2014).

To understand the growth of the Branhamites, it is important to be aware of the practices and strategies they adopt to attract people. This group focuses its criticism against central Christian doctrines and practices such as baptism, the trinity, and Jesus' deity. The movement organises annual general meetings in August, which is open to the public. Here, they advocate Branham as the 'prophet for the last days'. On such occasions, adherents distribute thousands of sermons, cassettes, books and photos of William Branham.

Another strategy of the Branhamites is to organise special funeral and burial services, and publicly assists those who have lost loved ones. The entire community is invited to attend the burial, which thousands of people do. Such an occasion often convinces other people to open their hearts to Branhamism.

The followers also organise campaigns at different universities among students as well as members of the staff. They even visit secondary schools to preach the end-time message of William Branham. This cult has specific offices that send out teams with the single aim of sharing the message of William Branham. They use radio and television channels to re-enforce Branham's message and his critique of the Apostles' Creed. 


\section{Historical background on the weakness of Christian mission work}

Their strategies are not the only reason why cultic groups such as the Jehovah's Witnesses and the Branhamites are growing in Central Africa. There are certain points of weakness in the way Christians handled matters in the Congo, which opened the door for these groups.

African religion is difficult to define, and it becomes even more complex in the context of African traditional life (Mbiti 1969:15). When the missionaries arrived on African soil, they did not focus on several central aspects of African Traditional Religions (ATRs). Examples of these aspects are the African view, the philosophy of Ubuntu and the importance of representation associated with the idea that 'I live because I belong'. The missionaries also did not focus on strong family and clan relationships, as well as the unique and rich customs and cultures (Ball 2015:85-95; Hesselgrave 1978).

The general African approach is more holistic than the more analytical Western worldview, and more group-oriented than individualistically inclined. This tendency can be seen in the common African practice of storytelling. It is also anthropocentric in the sense that man is the centre of the universe and God is transcendent and lives in the heavenly part of the universe (Hyden 2006). Africans have the view that 'a God who would separate the family or the clan is not a good God!' (Ball 2015:85-95). These life and worldviews should be understood and addressed for missionaries to really have impact on the new Christians.

To make matters worse, countries where the missionaries came from were involved in violence and slave trading alongside their evangelistic undertakings (Ball 2015:85-95). These weaknesses impaired the effective evangelisation of the Congo, and Kolwezi in particular. Missionaries failed to convince indigenous people to stop ancestor worshipping and other religious rituals including animism, worship of tree and animal spirits, polytheism, occultism, witch doctors and mediators. Within such a context, the missionaries failed to establish among their converts a true dependence on the God of the Bible (Ball 2015:117). Church members did not cease the practices listed above, which is evident from the ancestor worship shrine behind the house of almost every family in Katanga (Mufika 2017).

\section{Resistance to Christianisation due to syncretism}

The aim of this section is to demonstrate the importance of establishing a framework for Christian apologetics as basis to develop Christian education for the churches in Kolwezi. The previous paragraphs dealt with the penetration of the two cults, the Jehovah's Witnesses and Branhamites in Kolwezi. The truth is that the evangelism mission missed the vital point of total salvation for the people of Kolwezi. This was done by preaching a powerless gospel that did not change the people and their views. The door was opened to these two groups to find unsaved and ignorant people. Consequently, the Jesus that the two cults preached, is different from the one
Paul proclaimed to the church of his time (2 Cor 11:3-5). This also applies to the gospel preached by these cults and the spirit that drives them. This is not the Spirit of Jesus according to the New Testament testimony (2 Cor 11:3-5).

Africans were cognisant of God before colonisation. However, they were unaware of Jesus and his good news or gospel (Chalwe 2004:118). Many Africans felt that missionaries ignored their traditional beliefs and preached a diluted gospel that supported colonisation. As a result, numerous Africans were afraid to leave their ATR. Africans in general are deeply religious people (Ball 2015:114). Because of the collective nature of their culture 'religion and culture are synonymous - one cannot be separated from the other' (Mbiti 1969:15-16). Mbiti (1969:1) emphasises: 'Africans are notoriously religious ... religion permeates into all the departments of life so fully that it is not easy or possible to isolate it'.

The people in need of the undiluted gospel thus have a background provided by ATR. Therefore, effective communication should accompany the proper understanding of the traditional African beliefs and practices (Gehman 1989:19). The failure to appreciate the African way of life, caused the early missionary movement to be concerned about possible syncretism. As a result, they unfortunately denounced the local culture. Chalwe (2004:61) points out that 'by so doing, they built an artificial Christianity'.

Gehman (1989:19) notes that almost every Christian in Africa relies on elements of ATR in times of difficulty. He reveals that witchcraft and sorcery are large temptations. During emergencies, Africans feel the need to rely on the ancestors even those who became Christians. Mbiti (1969:238-239) argues that ATR was a preparatory revelation of God's will to the Africans. He considers it to be parallel, in intention and purpose, to the Old Testament.

This idea of God revealing himself to Africans through ATR, is commonly shared in liberal scholarship (Anderson 1971:146; 1986:171-175).

O'Donovan (1995:3-4) even identifies similarities among different African peoples. These aspects focus on community life, belief in a relationship between the living and the dead, fear, sickness and death, and belief in a relationship between the spiritual and physical world. They have the same set of priorities in life, hold a holistic view of life, and emphasise life events. Because of these commonalities, the role of ATR would give cause to consider the risk of syncretism.

To proceed from the premise above, the important role and task of Christian apologetics should be considered - as is done below.

\section{The task of Christian apologetics in Kolwezi}

To be of service to the churches, this study focused on the Jehovah's Witnesses and Branhamites from the perspective 
of Christian Apologetics. The critique centres on the dichotomy these doctrines offer: the one affirming only the humanity of Christ (Jehovah's Witnesses), and the other claiming only the divinity of Jesus (Branhamism). A response to the Jehovah's Witnesses, Branhamites and others, requires a focus on the person of Christ and how salvation is lived only by faith in Jesus (Kern 1995:11-13).

It should be noted that there are no apologists in the local Christian churches in Kolwezi. Apologetics is a novel approach to them. The majority of pastors and church leaders in the Pentecostal churches of Kolwezi have no formal training in or knowledge of apologetics.

\section{Training apologists}

When training Christians in apologetics, the first issue is the purpose, content and the methods that are applied. The aim is to answer and defend the Christian faith before members who are converted to cults, or who are being led away from basic Christian doctrines by those opposed to true Christianity. This raises the question as to what the approach should be to challenge movements such as the Jehovah's Witnesses and Branhamites.

Already a century ago, Stonelake (1919:108) reacted on pastoral training in Africa. At that time, he emphasised the importance of apologetics or 'educational evangelisation'. There is a need for well-structured apologetic programmes where the major orientation should be to engage in apologetic conversations. Through this project, local pastors and other Christian leaders can be trained to defend the Christian faith as well as reach out and win cult members in the immediate environment for Christ.

\section{Equipping the apologists}

As fishermen need materials for their task, evangelists and apologists also must be equipped. McGavran (1979) identifies the following requirements for Christians to do this work:

- $\quad$ knowledge of God (Pr 1:1-6; Jn 17:10-11);

- encounter with the Lord (Ac 9:16-16);

- indwelling of the Spirit of God (Jn 14:16-17);

- mandate and calling of the Lord (Mk 16:15-19);

- making disciples of Christ from every nation (Mt 28:18-20).

Kane (1974:57-64) supports these characteristics and adds that missionaries should be called by God in order to proclaim a relevant message. They should also be suitably trained in the basics of the theology and history of missiology, crosscultural missiology, and mission education. This position is also held by Fohle (2016:269). Apologists should be trained in the knowledge of God.

Furthermore, modern missionary apologists should be sent by the church to do mission work among the unsaved and unreached cults and other groups. It is important that churches provide literature if possible and help these apologists to become more task oriented.

\section{Mission among the cults as unreached people groups}

Apologists should be prepared to encounter cults - people perceiving themselves as the only real adherents to the truth of the gospel of Christ. Returning these individuals to the true faith requires intensive training and thorough assessment.

Students must be trained how to approach these individuals and converse with them, as well as how to maintain a missionary conduct among them. There are resources available in Africa that provide clear guidelines on working with Jehovah's Witnesses (see Stoker 2005:54-104), and Branhamites (Moreau 2010:1-20).

The concept of missiology implies the 'sending of someone to go out and preach the Good News about Christ to all creatures' (Mk 16:15-16). It is a calling and sending by the Lord to go and share the good news with those who are uninformed or do not understand the Scripture's message about God, and especially the saving work of Jesus Christ (Ac 8:26-40).

\section{Mission among the Jehovah's Witnesses}

The Jehovah's Witnesses also call themselves 'God's Organization' (WTBTS 1985:280). They criticise Christianity for being 'idol worshippers' (WTBTS 1989:1-10). This critique is based on the Jehovah's Witnesses' misunderstanding of the central Christian doctrine of the Trinity, while at the same time substituting their organisation as mediator in Jesus' place.

The society refers to salvation by deeds. In this regard, they alter the meaning of the word grace to mean 'to work hard for' it.

The way the Jehovah's Witnesses could be reached with the gospel in mid-Africa, will differ from, for instance, the United States - not in basic content, but in approach. The main reasons are the lower level of knowledge compared to their counterparts in the United States, as well as the hospitality character of African society as opposed to Western individualism.

\section{Mission among the Branhamites}

Similarly, as the approach to the Jehovah's Witnesses, apologists should consider the Branhamites as friends in need of knowing the true gospel which can bring salvation and transform their lives (2 Cor 5:17). Naturally, Branhamites will not acknowledge that they are resistant to change through the gospel of Christ. However, Moreau (2010) points out that 'they are very suspicious and resistant to any other message which is not from the prophet' (Branham 1963:40, 42). The Branhamites' negativity is due to the message adherents received from 'the prophet' based on his view of other churches as the 'mark of the beast' (Branham 1963:40). The accusation by Branham is a barrier that makes it difficult to receive the good news from members of Christian churches. For a breakthrough, apologists should befriend these mislead people and avoid unproductive heated discussions. 
The Branhamites in Kolwezi have come to understand that other churches also possess truth. Therefore, they can accept the work of these churches in terms of prayer and educational programmes, which they consider most reliable for their security. The Good Seed Global School in Kolwezi cater for a great number of Branhamist pupils. They are attracted by the quality of education, and the godly character of the school. Such engagement can provide a solid biblical foundation. It can also open the mentioned pupils' eyes to the falsehoods they were taught. However, it tends to be counterproductive to start with the false prophecies of Branham, seeing that his followers react violently when their prophet is criticised.

\section{Methodology to reach the cultic members}

Wherever the gospel has spread, there have always been people willing to interact with the proclaimed message. The Good Seed Global School in Manika Township in Kolwezi comprises approximately 1000 pupils of which $15 \%$ are Branhamites (Mufika 2017). The school teaches a course in religion on both primary and secondary levels. During class, pupils are made aware of their ignorance and sins. Those who are compelled, remain after class to have a dialogue with the teacher. The latter is a qualified pastor who can lead pupils to repentance and conversion by confessing Jesus as Lord and personal Saviour (Rm 10:1-12). Through this work, former Branhamite pupils and their parents testified how they came to know Christ.

Most of the churches in Kolwezi have members who are involved in evangelisation. The basics of Christianity are taught to new converts. However, one thing lacking is an apologetics committee at local and district level. Apologetics is needed to preserve the Christian doctrine (Geisler 2013:205). The need for such a church action is clear from the growth of the cults in Kolwezi and the rest of the DRC. Believers should be trained in apologetics, philosophy, theology, church history, social studies and various complementary fields. This would enable them to argue in a relevant way as the Apostle Paul had done (Ac 15; 1 Cor 15).

Christian apologetics is vital to every church when its beliefs are challenged. This helps, for example, to defend Christianity against other worldviews, religions, as well as cults. Apologetics also answers the criticisms against Christian doctrines. The answer of a Christian apologist can rectify, deny, correct and explain the position of Christianity in the way the Reformer, Martin Luther, did before his opponents (Stoker 2016). In Kolwezi, such an answer is indeed a reaction to the criticisms the Jehovah's Witnesses and Branhamites aimed against the Trinity, the nature of Christ and the resurrection of Christ (Branham 1963; WTBTS 1985).

Apologists' task is thus to defend the truth of the gospel. Therefore, they must understand the basic Christian doctrines and should be able to teach systematic theology to church leaders. The lack of such training has caused an increase in the attacks from the opponents of the basic Christian doctrine in Kolwezi.
The Early Church considered apologetics as crucial part of its daily existence (AD 0-500) when it faced controversies on the nature of Christ and his salvation. There were defensive speeches by the apostles, church fathers and apologists. They counter heresies, preserve the truth of Christ and defend against false accusations by the heathens directed at Christians before the Roman Emperor (Rusch 1980). Christ and his apostles taught us to 'beware of false prophets' (e.g. Mt 7:15; 10:16; Lk 10:3; Ac 20:29 and the whole book of Jude). Apologetics is an ongoing assignment of the church of all times and Christians should be trained from young to answer (apologia - 1 Pt 3:15) on their faith when needed.

\section{Recommendations and suggestions}

Theological seminaries should consider to train apologists by sending them in pairs into reaching cults and others that differ from the biblical teaching. They should work in love and kindness. Frequent reports should be received from the field after their return. The local church should become involved in this mission. Local churches are also called to create a new team of apologists, working together with the local evangelists for feedback after evangelisation. Conferences as well as radio and television debates can also aid this cause and relevant audio and video material should be produced.

\section{Avoid past mistakes}

In the past, the Christian churches in Kolwezi adopted a silence of suspicion towards cults such as the Jehovah's Witnesses and Branhamites. The churches in Kolwezi read their publications and observe the exodus of members.

However, no reaction has been sanctioned, neither within the church fellowship, nor outside the congregation. This silence is a complacency in the face of attempts to challenge the heart of the Christian doctrine. The statistics after 30 years of silence have become alarming. Church members should know the truth about these cults, their leaders and their doctrines.

This article recommends vigilance about the actions and publication of the so-called Christian cults in Africa. While spreading heresy, members of these groups should not be treated as enemies, but rather considered as 'lost brethren' due to heretical teachings. These followers are in dire need of salvation and faith in Christ (Rm 10:10-12). Therefore, complacent silence towards their criticism is counterproductive. Pastors should be equipped to prepare appropriate sermons and teachings to answer these critics apologetically and on relevant points.

\section{Focus on discipleship and Christian doctrine}

Early evangelisation in the DRC failed to emphasise discipleship. McGavran (1979) explains:

Effective evangelization is carried out by a joint effort by Pastor and people, where the Pastor performs a small but very important percentage of the total work. The people perform a large and important percentage. If any denomination or congregation 
wishes to become effective in its proclamation of the gospel, it must inspire and organize a substantial number of its men and women to become ardent and well-trained lay evangelists. (p. 131)

It has been found that especially women have not been discipled as needed (Lc 10:38-41). This is unfortunate, as women form the majority in most African churches, including Kolwezi. Educating women in religious matters can provide a strong stimulus for gospel preaching. Chalwe (2004:132) points out that tradition is the main stumbling block 'preventing the discipline or training of women for Christian service'. This lack of training has been detrimental to the success of mission work in Kolwezi per se. It is a mission and categorical imperative for the church not to make Christians, but to make disciples (Mt 28:19) of every member in the churches in Kolwezi. This also means making apologists of as many as possible (1 Pt 3:15).

\section{Open a school for Christian apologetics in Kolwezi}

During 1997 and 1998, a Bible school was opened in Kolwezi to train evangelists. This was the Ecole Nationale d'Evangelisation, Croissance de l'Eglise (ENECE). The school presented a diploma-level course of nine months under the programme of the International School of Evangelisation (ISE). To date, the ENECE has helped pastors and evangelists in Kolwezi attain knowledge, skills and an understanding of the missio Dei as well as Apologetics as discipline. Between 1997 and 1999, the school produced 24 qualified evangelists.

Furthermore, an institute named Institut Superieur de Theologie Evangelique de Kolwezi (ISTEKOL) also offers a diploma in Christian Apologetics in Kolwezi. Between 2006 and 2012, 20 theologians have qualified. The school train ordinary Christians, as well as those who converted from Branhamites and Jehovah's Witnesses for mission to reach these cults. In this way, many 'lost brethren' can be brought back to the true faith.

\section{Appropriate tools for apologetic mission}

Livingstone (Hesselgrave 1975:1) asserted: 'God had only one Son and He made that Son a missionary'. Every missionary follows in the steps of the Son of God, who condescended to earth 2000 years ago on a mission of redemption.

Kane (1975:16-17) explains that the word missionary is derived from Latin mitto, which means 'to send'. It is the equivalent of the Greek word apostle, which also means 'to send'. In the New Testament, the word apostle is used more than 80 times. In addition, Hebrews 3:1 refers to Christ as an apostle sent by God (Kane 1975:13).

Jesus chose 12 close followers, whom he called apostles. He trained and taught them, endowing them with apostolic authority. After the resurrection they were sent out to make disciples of all the nations (Mt 28:18-20). There are other men in the New Testament who came to be referred to as apostles. These include a second group, namely Barnabas, Timothy, Silas and others. In Acts, men are sent out by the Holy Spirit and the Church of Antioch (Ac 13:3-4). Most of the Acts of the Apostles cover the activities of these sent men-mostly Paul and his co-workers.

In the African context, churches do not have ample material means for mission. They only have people. Kane (1974) describes five requirements as 'tools' for a biblical missionary:

- Physically - in good health;

- Academically - trained as the apostles were taught by Christ for a relevant mission;

- Vocationally - called by God, directly or indirectly;

- Psychologically - have a balanced mind prepared for mission;

- Spiritually - be mature, gifted and equipped by God through his Spirit (1 Cor 12:1-10; Eph 6:12-19).

\section{Organise and send teams on mission}

In the context of Kolwezi, the need will be understandable to do 'inland' mission in the whole province of Lualaba where the city is situated. Hesselgrave (1980:85) defines inland mission as a 'home mission that needs leadership and strategy'.

The church is called by the Lord Jesus to understand and use three sources of missiology (Hesselgrave 1980:47). These are revelation through the Scriptures, reflection and sound thinking, and research entailing scientific observation. Evidently the churches should consider uniting in home mission activities across the province of Lualaba.

In practice, the local church should recruit volunteers for home mission to reach the Jehovah's Witnesses and Branhamites with their testimony and Scripture message. After recruitment, these people should be trained to work in the areas where they reside. They should be informed about the history of the respective movements, their doctrines, arguments and critique. Furthermore, the recruits should be taught different answers from the Bible to convince and persuade their brothers through the power of the Holy Spirit to believe in Jesus as God and Saviour (2 Pt 1:1). This training should include guidelines about engaging in a conversation with a follower of Jehovah's Witnesses or Branhamites and how to lead them to salvation by faith in Christ (Ac 8:26-40).

Green (1975:174) seemingly believes that Paul had little or no strategy and 'the gospel spread out in an apparently haphazard way as he obeyed the leading of the Holy Spirit and went through doors he opened'. What can be learnt from Green's view for missionary strategy, is to depend on the same Spirit. Conversely, McGavran (1955:25-35) points out that, while Paul was in Antioch, he devised a clear strategy to reach a large part of the Mediterranean world with the gospel.

For McGavran (1955), the missionary strategy is evident:

It is a matter of going where people are, preaching the Gospel, gaining the converts, gathering them into churches, instructing them in the faith, choosing leaders and commending believers to the grace of God. (pp. 25-35) 
There is room to adapt Paul's lifestyle and methodology for a missionary strategy that could target the mentioned cults in Kolwezi.

Hesselgrave (1980:58-59) redesigns the Pauline cycle based on an exposition of Acts: the missionary is commissioned (Acts 13:1-4; 15:39-40); the audience is contacted (13:14-16; $14: 1 ; 16: 13-15)$; the gospel is communicated (13:17-19; 16:31); hearers are converted $(13: 48 ; 16: 14-15)$; believers congregate (13:43); faith is confirmed (14:21-22; 15:41); leadership is consecrated (14:23); believers are commended (14:23; 16:40); relationship is continued (15:36; 18:23); and the sending churches are convened (14:26-27; 15:1-4). This redesigned missionary cycle can also be implemented in the apologetic strategy of the churches in Kolwezi.

\section{Organise conferences on Christian apologetics for mission}

The subject of Christian apologetics is strange and new among the Christians in Kolwezi. Ignorance about this discipline has caused the penetration of the churches by the mentioned cults in the city of Kolwezi. Unfortunately, numerous church members have been misled by the teachings of the Jehovah's Witnesses or Branhamites. Apologetics should be taught wisely with the aim of attracting the attention of all people. They should be persuaded in a simple way of the veracity of the Christian doctrine. As a result, even uneducated people would be able to see and believe Jesus as Son of God and Son of man.

The various churches should be called upon to participate in a missionary strategy. If the population understands and underwrites Christian apologetics for mission, the road will be open to proclaim Christ among the population of Kolwezi. The sister churches in Angola, Zambia, Namibia, Botswana and South Africa should also be invited to participate in regional conferences focusing on empowering apologists.

\section{Conclusion}

The number of church members lost to cults is high and it is unnecessary. One of the main reasons is that churches are not ensuring that their members are well grounded in the Christian faith. Churches should strengthen members as well as their teachers in the understanding of their faith, biblical beliefs and a strategy on winning people from cults.

The aim of responding to cults' criticism is to show church leaders that they should be able to read, explore and analyse critical challenges from cults. In addition, these leaders should be able to compare the teachings of the cults to the Scripture message. This article recommends that Christian apologists should be established in local congregations in Kolwezi and elsewhere in Africa. For this aim, students should be trained and enabled to approach cult members with love, friendliness and true biblical doctrine. Such a missionary intervention can change the current development of the situation in Kolwezi, the Congo and transfer this transformation to other parts of Africa.
Furthermore, the aim is offering African Christians a way to discuss orthodox Christian teachings with cults such as Jehovah's Witnesses, Branhamites as well as other groups focusing on Africa, such as the Mormons (Latter Day Saints).

Such a strategy requires a focus on the person of Christ, and salvation which is lived only by faith in Jesus Christ.

However, syncretism persists despite various attempts at Christianising the DRC and Africa. The main cause is ignorance about the centrality of the person of Christ in members' faith. Christ is not only disfigured by modern preachers, but he is absent also at the centre of many hearts of church members.

The cults' criticism targets the veracity of the Christian creeds historically, which affirm both the humanity and divinity of Christ. The task of Christian apologists in the 21st century is important - turning the tide of lost members to cults, back to Christianity and a personal relationship with the triune God of Scriptures.

\section{Acknowledgements Competing interest}

The authors have declared that no competing interest exist.

\section{Authors' contributions}

This article stems from the doctoral research work of M.B.M. under supervision of H.G.S. The article was written by M.B.M. with input and guidance of H.G.S.

\section{Ethical consideration}

This article followed all ethical standards for carrying out research.

\section{Funding information}

This research received no specific grant from any funding agency in the public, commercial, or non-for-profit sectors.

\section{Data availability statement}

Data sharing is not applicable to this article as no new data were created or analysed in this study.

\section{Disclaimer}

The views and opinions expressed in this article are those of the authors and do not necessarily reflect the official policy or position of any affiliated agency of the authors.

\section{References}

Anderson, W.B., 1971, The unfolding drama of the Bible: Eight studies introducing the Bible as a whole, Follett, Westchester, II.

Anderson, W.B., 1986, Understanding the Old Testament, 4th edn., Pearson, New York, NY.

Baker, D.W. ,2006, Historiography of the Old Testament, Elsenbraus, Winona Lake, IN. 
Ball, K.R., 2015, Introduction to Christian apologetics, Class notes of 2015, Trans-Africa Theological College, Kitwe.

Bowman, R.M., 1995, Jehovah's Witnesses, Zondervan, Grand Rapids, MI.

Branham, W.M., 1963, Christ is the mystery of God revealed, Voice of God Recording, Jeffersonville, IN.

Burton, W.F.P., 1961, Luba religion and magic in custom and belief, Musée Royal de l'Afrique Centrale, Brussels.

Chalwe, A., 2004, 'Contextualization minus syncretism: Impacting Zambia with the Christian message', MA dissertation, North-West University, Potchefstroom Christian message, MA
Ccampus, Potchefstroom

Dencher, T., 1961, The Watch Tower heresy versus the Bible, Moody Press, Chicago, IL.

Fohle, L.L.M., 2016, 'Transforming missiology: An alternative approach to missiological education with special reference to the DR Congo', PhD thesis, North-West University, Potchefstroom.

Garrard, D.J., 2008, The history of Congo mission/30e Communaute Pentecotiste au Zaire from 1915 to 1982, Hail, Mattersey.

Gehman, R.J., 1989, African traditional religion in biblical perspective, Kijobe Kesho, Nairobi.

Geisler, N.L., 2013, Christian qpologetics, 2nd edn., Baker Academic, Grand Rapids, MI. Green, O.B., 1975, The gospel of John, vol. 2, Chapters 8-14, Gospel House, SC.

Gruss, E.C., 1970, Apostle of denial, Baker Book House, Grand Rapids, MI.

Gruss, E.C., 1979, Apostle of denial, Baker Book House, Grand Rapids, MI.

Hesselgrave, D.J., 1975, Theology and mission, Baker Book House, Grand Rapids, MI.

Hesselgrave, D.J., 1978, Theology and mission, Baker Book House, Grand Rapids, MI.

Hesselgrave, D.J., 1980, Planting churches cross-culturally: A guide for home and foreign missions, Baker Book House, Grand Rapids, MI.

Hyden, G. 2006. African Politics in comparative perspective. Cambridge University Press, New York, NY.

Kane, J.H., 1974, Understanding Christian mission, Baker Book House, Grand Rapids, MI. Kane, J.H., 1975, The making of a missionary, Baker Book House, Grand Rapids, MI. Kern, H., 1995, How to respond to Jehovah's Witnesses, Concordia, St. Louis, MO.

Kisangani, E.F. \& Bobb, S., 2010, Historical dictionary of the Democratic Republic of the Congo, Scarecrow, Plymouth.
Malula, A.J., 1970, The Church is the state, and the state is the is the church for our people, Archidiocese of Kinshasa, Kinshasa.

Mbiti, S., 1969, African religion and philosophy, Morris \& Gibbs, London.

McGavran, D., 1955, The bridge of God, Friendship Press, New York.

McGavran, D., 1979, Zaire: Midday in missions, Judson Press, Valley Forge, PA.

Moreau, A.S., 2010, 'Branhamites, Kampala, East Africa', Journal Education of Theology (Unpublished).

Mufika, B.M., 2017, 'Jesus: "God, the only God, or not God": A study of the Jehovah's Witnesses and Branhamism's influence in Kolwezi, DRC', PhD dissertation, North-West University, Potchefstroom Campus.

O'Donovan, W., 1995, Biblical Christianity perspective, Paternoster, Carlisle.

Palmier TV, 2014, Kolwezi, August.

Rusch, W.G., 1980, The Trinitarian controversy, Fortress Press, Philadelphia, PA

Stoker, H.G., 2005, 'Jehovah's witness, a Christian cult?', Unpublished dissertation, North-West University, Potchefstroom.

Stoker, H., 2016, 'Is Jesus and the Holy Spirit God?', Unpublished dissertation, North-West University, Potchefstroom.

Stonelake, A., 1919, Congo past and the present, World Domination Press, London.

Wilson, D.J., 1988, 'Branham, William Marrion (1990-65)', in S.M. Burgess \& G.B. McGee (eds), Dictionary of Pentecostal and charismatic movements, pp. 95-97, Regency Reference Library, Grand Rapids, MI.

Watchtower Bible and Tract Society (WTBTS), 1941, Let God to be true, Watchtower Bible and Tract Society, Brooklyn, NY.

Watchtower Bible and Tract Society (WTBTS), 1971, Aid to Bible understanding, Watchtower Bible and Tract Society, Brooklyn, NY.

Watchtower Bible and Tract Society (WTBTS), 1985, Reasoning from the Scriptures, Watchtower Bible and Tract Society, Brooklyn, NY.

Watchtower Bible and Tract Society (WTBTS), 1989, The time of the end, Watchtower Bible and Tract Society, Brooklyn, NY.

Watchtower Bible and Tract Society (WTBTS), 2004, Yearbook 2004, Watchtower Bible and Tract Society, Brooklyn, NY. 